\title{
Communication
}

\section{Deadwood, Soil and Carabid Beetle-Based Interaction Networks-An Initial Case Study from Montane Coniferous Forests in Poland}

\author{
Magdalena Kacprzyk $^{1, *}$, Ewa Błońska ${ }^{2}$ (i) and Tadeusz Wojas ${ }^{1}$ \\ 1 Department of Forest Ecosystems Protection, University of Agriculture in Krakow, Al. 29 Listopada 46, 31-425 \\ Kraków, Poland; tadeusz.wojas@urk.edu.pl \\ 2 Department of Ecology and Forest Silviculture, University of Agriculture in Krakow, Al. 29 Listopada 46, \\ 31-425 Krakow, Poland; ewa.blonska@urk.edu.pl \\ * Correspondence: magdalena.kacprzyk@urk.edu.pl
}

Citation: Kacprzyk, M.; Błońska, E.; Wojas, T. Deadwood, Soil and Carabid Beetle-Based Interaction Networks-An Initial Case Study from Montane Coniferous Forests in Poland. Forests 2021, 12, 382. https://doi.org/10.3390/f12040382

Academic Editor: Zoltán Elek

Received: 6 March 2021

Accepted: 22 March 2021

Published: 24 March 2021

Publisher's Note: MDPI stays neutral with regard to jurisdictional claims in published maps and institutional affiliations.

Copyright: (c) 2021 by the authors. Licensee MDPI, Basel, Switzerland. This article is an open access article distributed under the terms and conditions of the Creative Commons Attribution (CC BY) license (https:// creativecommons.org/licenses/by/ $4.0 /)$.

\begin{abstract}
In four study plots located in silver fir and Scots pine stands in Magura National Park (southeastern Poland), the relationships between the occurrence and biomass of epigeic carabids, the volume of deadwood and soil biochemical properties were investigated. Thirteen carabid beetle species from the genera Abax, Carabus, Molops and Pterostichus were captured. Rare epigeic carabid species in the fauna of Poland and Europe, such as Carabus glabratus (Paykull), Carabus sylvestris (Panzer) and Abax schueppeli (Germar), were recorded. The number of carabid individuals and species captured as well as the mean individual biomass index at different elevations and in forests of different tree compositions differed significantly. There were no correlations between deadwood volume, carabid abundance and the mean individual biomass of the carabid beetles. The mean individual Carabidae biomass increased with elevated $\mathrm{pH}$, soil carbon content, soil dehydrogenase activity and the number of stumps.
\end{abstract}

Keywords: dead trees; decomposition degree; epigeic beetles; dehydrogenases

The relationship between the occurrence of carabid beetles and deadwood has been poorly understood thus far. Few studies have demonstrated positive associations between ground beetle abundance, species richness and diversity and the amount (number and volume of trees) of coarse woody debris [1-3]; however, the extent to which the occurrence of carabid beetles depends both on the quantity and quality of deadwood remains unresolved. Moreover, understanding the changes in carabid biomass, which have not yet been studied, together with species composition as a result of deadwood presence could allow us to expand our knowledge in this area. The individual biomass of carabid beetles (mean individual biomass, MIB) is strongly and positively related to the biomass of the macrofauna responsible for litter decomposition, which is reflected in the quantity and quality of organic matter necessary for the proper functioning of forest ecosystems and the nutrient cycle [4-6].

Higher macrofaunal biomass and faster decomposition of the litter layer result in increased carbon (C) content in mineral soil and have positive effects on soil microbial activity. The presence of dead trees in forests stimulates biological activity in soils and the development of soil microorganism populations. Błońska et al. [7] and Piaszczyk et al. [8] proved an increase in dehydrogenases (DHs - enzymes that provide information about the soil condition and the microorganism activity in the soil; $[9,10])$ activity in the vicinity of stumps and dead trees lying on the ground. The chemical substances that result from the death and decomposition of woody tissues reach the organic layer of the soil and contribute to the overall contents of carbon and other nutrients, which are food sources for soil-litter invertebrates and are associated with the occurrence of the prey of predatory carabid beetles [11-14]. The soil organic matter content has a significant impact on carabid 
biomass. Szyszko et al. [15] showed a significant increase in the MIB value of epigeic carabid beetles together with an increase in the carbon content of a forest stand. Changes in soil parameters, and consequently in carabid biomass under the influence of deadwood, may have a relationship with the degree of its decomposition, determined by the form and species composition of a stand and microenvironmental conditions [16,17]. An increase humidity, decrease temperature along an altitudinal gradient may have consequences in decrease of MIB of carabid beetles [18,19]. At the same time climate features (temperature, precipitation), as well as deadwood species and its physical characteristics (density) may influence on quantity and quality of soil organic matter and dead wood decomposition rate [20-23].

The aim of this study was to compare carabid beetle assemblages (species composition and richness) and MIB index values in Scots pine and silver fir stands in relation to deadwood stock, decomposition degree and selected chemical soil parameters. The following hypotheses were tested: (1) carabid abundance and biomass will increase with an increasing amount and volume of deadwood; (2) the individual carabid beetle biomass is positively correlated with the biological activity of soils; and (3) deadwood affects soil biological activity and carabid biomass differently in fir and pine forest stands at different elevations (thermal and humidity conditions) as a result of the impact on the quantity and quality of soil organic matter and rate of decomposition.

The study was conducted in 2016 in four stands located in Magura National Park in the western Carpathians in southeastern Poland $\left(49^{\circ} 30^{\prime} 00^{\prime \prime} \mathrm{N}, 21^{\circ} 30^{\prime} 00^{\prime \prime} \mathrm{E}\right)$. In two of the stands, the dominant tree species was silver fir (Abies alba Mill.), while in the other two stands Scots pine (Pinus sylvestris L.) was the forest-forming tree species. In the pine stands, the species admixture included larch (Larix decidua Mill.), ash (Fraxinus excelsior L.), common beech (Fagus sylvatica L.), European hornbeam (Carpinus betulus L.), maple (Acer spp.), birch (Betula spp.) and rowan (Sorbus aucuparia L.). The fir stand species composition was less varied, with an admixture of common oak (Quercus robur L.) and common beech. For each dominant tree species, two elevations were evaluated: the foothills, between 300 and $450 \mathrm{~m}$ above sea level, and the lower montane zone at $600 \mathrm{~m}$ a.s.l. The fir stands were 60 years old, while the pine stands were 50 years old. All the stands had a moderate density, i.e., broken canopy closure. The following symbols were assigned to the study sites: SPF-Scots pine stand in the foothill zone; SPLM-Scots pine stand in the lower montane zone; SFF-silver fir stand in the foothill zone; and SFLM-silver fir stand in the lower montane zone.

In each of the stands, study plots with area of 25 ares $(50 \mathrm{~m} \times 50 \mathrm{~m})$ were established for soil sampling and the inventories of deadwood and carabid beetles were performed within these plots. The adopted inventory procedures of deadwood and soil sampling design were described in detail by Błońska et al. [7].

Carabid beetle monitoring was performed using pitfall traps $(9 \mathrm{~cm}$ diameter and $0.5 \mathrm{~L}$ capacity). In each study plot, six traps were placed at a minimum distance of $20 \mathrm{~m}$ from each other. Four traps were arranged within $50 \mathrm{~cm}$ of dead prostrate trees (two traps near dead prostrate trees in decay stage III and two traps near dead prostrate trees in decay stage IV), whereas two traps were placed within $50 \mathrm{~cm}$ of stumps (one trap near the stump in decay stage III and one trap near the stump in decay stage IV). A $30 \mathrm{~m}$ distance from the edge of each study plot for pitfall traps was adopted. A total of 24 pitfall traps were installed. The pitfall trap catch was retrieved at weekly intervals from 30 April to 15 August. All the plots were sampled on the same day. At every turn the beetles were identified to the species level and weighed to the nearest $0.1 \mathrm{mg}$ using an electronic scale (WPE 600, Radwag Balances and Scales). After weighing each beetle, they were released at a distance of $30 \mathrm{~m}$ from the study plot.

To analyze the beetle assemblages within the biocenosis, an individual dominance in$\operatorname{dex}\left(D_{\mathrm{i}}\right)$, a quantitative ecological indicator that reflects the percentage share of individuals of one particular species found among the total number of individuals of all species found in the studied ecosystem, was utilized. To compare the forest habitats, the Simpson domi- 
nance (c) index, which relates a coefficient of importance for each species (biomass) to the sum of the coefficients of importance, was used [24]. The Shannon diversity index $\left(\mathrm{H}^{\prime}\right.$; [25]) was used to evaluate species diversity. Based on carabid biology and ecology [26-28], the beetles were classified into the following ecological groups:

(a) Trophic-large zoophages with body lengths greater than $15 \mathrm{~mm}$, small zoophages with body lengths less than $15 \mathrm{~mm}$ or hemizoophages (i.e., omnivorous species);

(b) Habitat-forest, eurytopic or open area species; and

(c) Geographical-Palearctic, Holarctic or European species.

Taking into account carabid humidity preferences, we distinguished the following groups:

(d) Hygrophilous species, whose occurrence is related to high water content in the soil;

(e) Mesophilous species, which live in areas characterized by moderate soil moisture; and

(f) Xerophilous species, which can occur in an environment with low water availability.

The carabid nomenclatures were based on de Jong et al. [29].

The effect of elevation and tree stand species composition on the deadwood volume was examined with a Mann-Whitney $U$ test, whereas the differences in the mean values of the soil properties were evaluated by the Kruskal-Wallis test. A generalized linear model (GLM) was used to investigate the effect of deadwood localization, volume and tree species on ground beetle species richness, number of individuals and biomass. Principal component analysis (PCA) was used to evaluate the relationships between soil properties, deadwood and carabids characteristics. The considered variables included soil characteristics, such as $\mathrm{pH}, \mathrm{C}$ content which has a significant potential impact on insect occurrence [30,31], dead prostrate tree and stump volume, deadwood decomposition stage, number of individuals and species, carabid mean individual biomass and tree species. Statistical significance was assigned at $\alpha=0.05$. The statistical analyses were performed with Statistica 12 software.

A total of 200 carabid beetles representing 13 species and four genera, namely Abax, Carabus, Molops and Pterostichus, were captured in the study plots. All the species were characteristic of forest habitats. Most of the carabid beetles found in the studied stands were classified as large zoophages tolerant to moisture conditions. European species with a small distribution range were distinctly more prevalent than those with broad geographical distributions (Table 1). The number of carabids caught in pine stands was $45 \%$ higher than the number found in the fir stands. Similarly, the pine stands had a higher number of species. The highest species diversity was recorded in the SPF. In contrast, this site was characterized by the lowest Simpson species richness index (0.74), which was $27 \%$ lower than the highest recorded value, which was found in the SFF (0.98) (Table 1).

In each study plot, the most numerous carabid beetles were: Abax schueppeli (Germ.), Abax ovalis (Duft.) and Pterostichus oblongopunctatus (Fabr.) (Table 1). Abax schueppeli occurred most frequently in the SPLM study site, where it represented $38 \%$ of all the beetles caught. The next most numerous carabids, A. ovalis and P. oblongopunctatus, represented $15 \%$ and $18 \%$, respectively, of the total species abundance. The smallest frequency was noted for Abax parallelus (Duft.) and Carabus glabratus Paykull at the SPLM study site (2\%). Carabus coriaceus L. and Carabus arcensis Herbst. were only recorded at the SPF site (Table 1). Overall, the highest MIB value was obtained at the SPF site (341 mg); the MIB value at this site was $28 \%$ higher than the lowest index value, which occurred at the SFF site (266 mg; Table 1).

A total of 130 different deadwood items were inventoried. These samples represented approximately $10 \%$ of the total inventoried live tree volume (Table S1). The most numerous deadwood form, stumps (number $N=56$ ) reached ca. $15 \%$ of the total number of living trees in the study sites and ca. $43 \%$ of the total number of deadwood. The deadwood volume significantly changed with elevation $(Z=2.41 ; p=0.016)$. Independent of the species composition of the stand, deadwood was more abundant in the foothills than in 
the lower montane zone. However, the difference in deadwood volume between the fir and pine stands $(27 \%)$ was not statistically significant $(Z=1.42 ; p=0.154)$.

Table 1. The characteristics of carabid species, their dominance structure, abundance and beetles' assemblages indices.

\begin{tabular}{|c|c|c|c|c|c|c|c|c|}
\hline \multirow{2}{*}{$\begin{array}{c}\text { Species } \\
\text { (** Red List Species: } R, \text { Rare) }\end{array}$} & \multicolumn{4}{|c|}{ Ecological Features * } & \multicolumn{4}{|c|}{ Study Site } \\
\hline & A & B & $\mathrm{C}$ & D & SFF & SFLM & SPF & SPLM \\
\hline Abax ovalis (Duft.) & SZ & $\mathrm{F}$ & EU & mez & 25.9 & 17.1 & 19.8 & 12.8 \\
\hline Abax schueppeli (Germ.) ${ }^{* *} \mathrm{R}$ & $\mathrm{LZ}$ & $\mathrm{F}$ & EU & mez & 18.5 & 14.3 & 38.5 & 12.8 \\
\hline Abax parallelus (Duft.) & SZ & $\mathrm{F}$ & EU & mez & 7.4 & 11.4 & 5.5 & 2.1 \\
\hline Carabus arcensis (Herbst) & $\mathrm{LZ}$ & $\mathrm{F}$ & PA & mez & & & 7.7 & \\
\hline Carabus coriaceus (L.) & $\mathrm{LZ}$ & $\mathrm{F}$ & EU & mez & & & 3.3 & \\
\hline Carabus linnei (Panzer) & $\mathrm{LZ}$ & $\mathrm{F}$ & EU & mez & 7.5 & 11.4 & 2.2 & 23.4 \\
\hline Carabus glabratus (Paykull) ${ }^{* *} \mathrm{R}$ & LZ & $\mathrm{F}$ & EU & hig & & 8.6 & & 2.1 \\
\hline Carabus sylvestris (Panzer) ${ }^{* *} \mathrm{R}$ & $\mathrm{LZ}$ & $\mathrm{F}$ & EU & mez & 3.7 & & 2.2 & \\
\hline Carabus violaceus (L.) & $\mathrm{LZ}$ & $\mathrm{F}$ & PA & hig & & 2.9 & & 10.6 \\
\hline Molops piceus (Panzer) & SZ & $\mathrm{F}$ & EU & mez & 3.7 & 5.7 & 6.6 & 4.3 \\
\hline Pterostichus burmeisteri (Heer) & SZ & $\mathrm{F}$ & EU & mez & 7.5 & 11.4 & 2.2 & 4.3 \\
\hline Pterostichus niger (Shall.) & $\mathrm{LZ}$ & $\mathrm{F}$ & PA & hig & & 2.9 & 2.2 & 6.4 \\
\hline Pterostichus oblongopunctatus (Fabr.) & SZ & $\mathrm{F}$ & PA & mez & 25.9 & 14.3 & 9.9 & 21.3 \\
\hline & $(\mathrm{N})$ & & & & 27 & 35 & 91 & 47 \\
\hline & & & & & 266 & 279 & 341 & 271 \\
\hline Simp & tance & & & & 0.018 & 0.031 & 0.207 & 0.055 \\
\hline Shann & sity ( & & & & 0.117 & 0.132 & 0.156 & 0.148 \\
\hline Simp & rsity & & & & 0.98 & 0.97 & 0.79 & 0.94 \\
\hline
\end{tabular}

* A-trophic group (large zoophages—LZ, small zoophages—SZ); B-ecological group (forest species-F); C-geographical group (Palaearctic-PA species, European-EU); D-humidity preferences (hygrophilous species-hig, mesophilous species-mez); ** Red-listed species were classified according to the 2002 Red List of Threatened and Endangered Animals in Poland [32].

The soils of the study sites differed significantly in terms of $\mathrm{pH}(\mathrm{H}=30.29 ; p=0.000$ for $\mathrm{pH} \mathrm{H}_{2} 0 ; \mathrm{H}=31.89 ; p=0.000$ for $\left.\mathrm{pH} \mathrm{KCl}\right), \mathrm{C}$ content $(\mathrm{H}=11.40 ; p=0.009)$, the $\mathrm{C} / \mathrm{N}$ ratio $(\mathrm{H}=14.40 ; p=0.002)$ and $\mathrm{DH}(\mathrm{H}=7.80 ; p=0.048)$ (Table S1). The highest $\mathrm{pH}$ occurred in the SPLM soil. Conversely, the lowest soil $\mathrm{pH}$ was recorded in the SFLM soil. DH was highest in the SPF. The $\mathrm{C}$ content and $\mathrm{C} / \mathrm{N}$ ratio were highest in the SFLM soil; they were $105 \%$ and $21 \%$ higher, respectively, than the lowest values, which were found in the soil of the SPLM stand. The nitrogen content differed slightly between the study sites.

An effect of elevation and an effect of tree species, as well as an interaction effect, on the carabid assemblages has been proven (Table 2). There was a higher number of carabid specimens $(54 \%)$ and higher carabid biomass $(16 \%)$ in the pine stands than in the fir stands. In our opinion, these findings may have resulted from the complex effect of microhabitat factors and the share of particular deadwood forms. The occurrence of most carabid beetle species is related to the presence of stumps and dead fallen trees or logs $[4,33]$. Among the inventoried deadwood timber in the pine stands, stumps represented the largest volume share (ca. $43 \%$ of the total volume of dead wood), while in the fir stands snags (ca. $26 \%$ of the total volume of dead wood) and dead standing trees (23\% of the total volume of dead wood) were dominant. Whereas mixed stands are characterized by a greater variety of species than that found in single-species forests [3,34], compared to the more simplified species structure in the fir stands, the greater number of tree species in the pine stands probably underlies the findings in this study. We also noted a decrease in carabid abundance and species diversity with increasing height above sea level.

The elevation gradient and changing environmental conditions also significantly affect carabid body size and biomass. Usually, the same carabid species exhibit a reduction in body size and biomass with increasing elevation and changing vegetation [19,35]. On the other hand, Fraser and Bassett [36] demonstrated that in grasslands, carabid dry weight increases at higher elevations compared to that in lower elevations. We found (in both the pine and fir stands) a decrease in the mean biomass of the Abax specimens as elevation increased whereas, Pterostichus and Molops specimens showed an opposite trend. When considering the forest tree species, there were similar trends in the MIB as there were for species abundance and diversity. Our observation is likely influenced by the microhabitat structure created by deadwood (in addition to elevation). Deadwood and its immediate 
vicinity are a specific microhabitat characterized by, as a rule, stronger moisture and more stable moisture conditions. Habitat type is highly important for carabid body length [37,38]. Complicating the variation in the pattern of insect body size along elevation gradients, there can be a positive and negative dependence on elevation among different species [39]. Jung et al. [40] verified the significant effect of habitat type on ground beetle subfamily level distributions in mountainous regions. At the same time, litter depth (independent of elevation) appeared to play a more than altitude important role in carabid beetle species richness [41,42]. This trend may also apply to the biomass of carabids.

Table 2. Results of multivariate analysis of variance based on the general linear model (GLM) for the carabids number and biomass, including the altitude of the deadwood (DW) plots and its quantity.

\begin{tabular}{ccccccc}
\hline Effect & \multicolumn{2}{c}{ No of Individuals } & \multicolumn{2}{c}{ No of Species } & \multicolumn{2}{c}{ MIB } \\
& $\mathbf{F}$ & $\boldsymbol{p}$-Value & $\mathbf{F}$ & $\boldsymbol{p}$-Value & F & $\boldsymbol{p}$-Value \\
\hline Elevation m a.s.l & 5.119 & $\mathbf{0 . 0 2 5}$ & 9.231 & $\mathbf{0 . 0 0 3}$ & 10.860 & $\mathbf{0 . 0 3 0}$ \\
DW species & 17.114 & $\mathbf{0 . 0 0 0}$ & 24.074 & $\mathbf{0 . 0 0 0}$ & 27.270 & $\mathbf{0 . 0 0 6}$ \\
Elevation m a.s.1 $\times$ DW species & 4.748 & $\mathbf{0 . 0 3 1}$ & 8.767 & $\mathbf{0 . 0 0 4}$ & 19.958 & $\mathbf{0 . 0 1 1}$ \\
DW volume & 1.520 & 0.219 & 0.565 & 0.453 & 0.075 & 0.798 \\
DW species $\times$ DW volume & 2.598 & 0.109 & 1.040 & 0.201 & 0.233 & 0.654 \\
Elevation m a.s.l $\times$ DW volume & 1.851 & 0.176 & 1.007 & 0.317 & 0.279 & 0.625 \\
DW species $\times$ Elevation m a.s.l $\times$ & 1.570 & 0.212 & 0.767 & 0.382 & 0.071 & 0.803 \\
DW volume & & & & & &
\end{tabular}

Notably, the deadwood volume was not a significant factor for either the number of carabid species or specimens recorded during the study period. Deadwood volume did not also influence the average individual biomass of the carabid beetles caught at the study sites (Table 2). Ground beetles use deadwood mainly for shelter and wintering purposes, and to a lesser extent for hunting, hence the response of insects to changes in the volume of dead trees may be less pronounced than for saproxylophagous insects directly related to the presence of deadwood and its quantity [43-45]. Moreover, the relation between carabid beetle abundance and dead wood volume may be more visible in in clear-cuts or stands disturbed in the past by windthrow, where, compared to forests, its presence is crucial for providing shelter from adverse climatic conditions and survival [46,47]. The small spatial scale (not exceeding $0.5 \mathrm{ha}$ ) possibly also explains why we did not observe a positive association between carabids and deadwood quantity [48-50].

The PCA confirmed that high MIB and carabid species richness were strong associated with high soil microbial activity, expressed by the DH. Furthermore, these parameters were positively correlated with soil $\mathrm{pH}$ and the volume of stumps. Higher MIB values were found in the pine stands. Larger soil organic carbon stocks were recorded on study plots with a higher proportion of dead trees in decay stage IV (Figure 1).

Food resource availability is one of the key determining factors for carabid beetle occurrence [51]. According to Błońska et al. [7] and Piaszczyk et al. [8], the presence of forest deadwood stimulates soil biological activity. The increase in enzymatic activity can be associated with the transfer of deadwood decomposition products to the soil located directly beneath it [8]. We observed the highest MIB values at sites with the greatest number of stumps. These results confirm the equally important role of stumps (similar to that of large sections of deadwood) on carabid beetle diversity [52].

Similarly, as the soil $\mathrm{pH}$ and $\mathrm{C}$ content increased, the mean individual biomass of carabid beetles and the number of species increased. Other studies revealed the positive influence of relatively high soil $\mathrm{pH}$ and $\mathrm{C}$ and $\mathrm{N}$ content on the abundance and species richness of ground beetle communities [53-57]. In our analyses, the PCA confirmed the relationship between $\mathrm{pH}$, soil microbial activity and the abundance and richness of the carabid species. Under conditions of higher $\mathrm{pH}$, microorganisms and macrofauna that participate in the decomposition of soil organic matter are stimulated. The more efficient distribution of soil organic matter in conditions of higher $\mathrm{pH}$ at the study sites with pine wood has been confirmed by a lower $\mathrm{C} / \mathrm{N}$ ratio. Jukes et al. [58] showed that the most 
significant factors affecting carabid community composition were latitude, canopy structure and soil organic matter. Soil organic matter affects the number of organisms participating in its decomposition, which constitutes the food base for organisms located higher in the trophic chain.

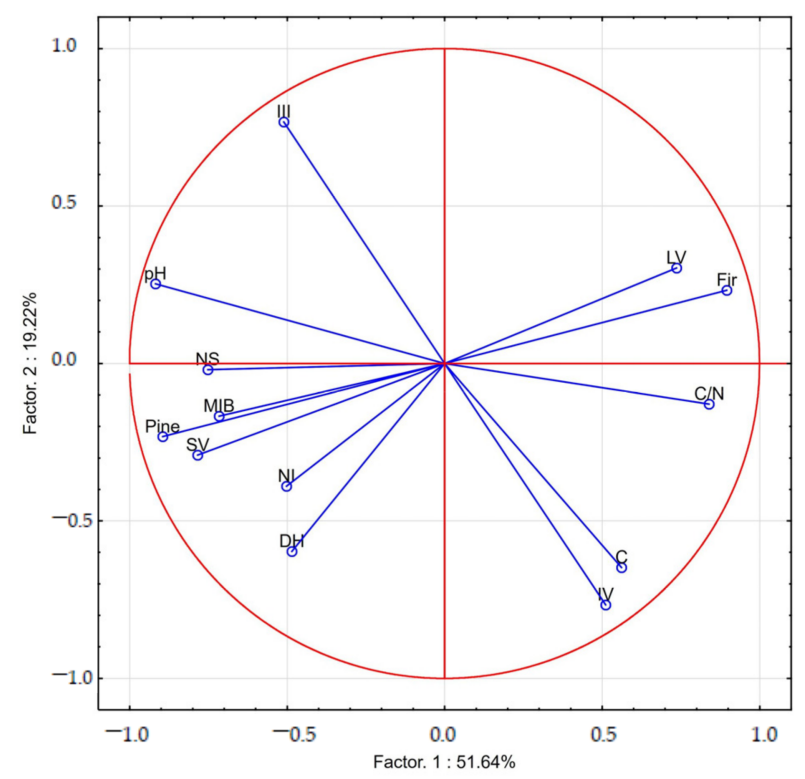

Figure 1. The projection of variables on a plane of the first and second factor in soil around deadwood (III, IV-decomposition class; MIB — mean individual carabid biomass, NI-the number of carabid individuals; NS - the number of carabid species; SV-volume of stumps; LV-volume of logs; $\mathrm{DH}-$ dehydrogenase activity.

The soil directly impacted by deadwood is richer in organic matter as a result of deadwood decomposition. This process increases the availability of different forms of soil nutrients [59]. The fir stands had a higher $\mathrm{C} / \mathrm{N}$ ratio than the pine stands, a result indicative of a lower organic matter decomposition rate. The obtained results confirm the importance of the wood species of a dead tree for the rate of its decomposition, and as a consequence the amount of nutrients released into the soil. Our results indicate that the amount of carbon substrates released from decaying wood determines carabid occurrence. Lasota et al. [59] and Piaszczyk et al. [8] proved the importance of the wood species of dead trees in shaping soil properties as a result of the released substrates.

In conclusion, the presence of deadwood significantly influenced the soil biological activity and the mean individual biomass of the carabids. Carbon accumulation increased to a greater extent in the soils closer to the logs and stumps, and these areas also had higher DH and an elevated MIB index. The results indicate the significant role that stumps play in soil biological activity and the carabid beetle occurrence. This finding can be particularly important in state forests, where leaving large pieces of deadwood is often not allowed. Further large- scale investigations, enabling us to explore links between carabid beetle biomass, the volume and quality of deadwood and soil properties, will be of high importance for our understanding of species interactions to develop management strategies oriented towards the protection of species and their habitats.

Ethical Approval: The study was performed in Magura National Park, and samplings were permitted by the Polish Ministry of the Environment. The methodology and applied devices for carabid beetle trapping did not pose a threat to insects that occur in the examined area and also did not negatively impact Magura National Park.

Supplementary Materials: The following are available online at https:/ / www.mdpi.com/1999-490 7/12/4/382/s1, Table S1: Quantity structure of deadwood and soil parameters (mean \pm SD) at the study sites. 
Author Contributions: Conceptualization, M.K., E.B.; methodology, M.K., E.B.; formal analysis, M.K., E.B., T.W.; writing-original draft preparation, M.K., E.B.; writing-review and editing, M.K., E.B. and T.W.; visualization, M.K. and E.B. All authors have read and agreed to the published version of the manuscript.

Funding: The study was financed by a subvention from the Ministry of Science and Higher Education of the Republic of Poland for the University of Agriculture in Krakow, Department of Forest Ecosystems Protection (SUB/040013-D019); Department of Ecology and Forest Silviculture (SUB/040012-D019).

Data Availability Statement: The data presented in this study are available on request from the corresponding author. The data are not publicly available due to policy of the institute.

Acknowledgments: The authors would like to thank the management of Magura National Park for enabling this research and Anna Spólnik for helping in collect carabid beetles.

Conflicts of Interest: The authors declare no conflict of interest. The funders had no role in the design of the study; in the collection, analyses or interpretation of the data; in the writing of the manuscript; or in the decision to publish the results.

\section{References}

1. Pearce, J.L.; Venier, L.A.; McKee, J.; Pedlar, J.; McKenney, D. Infuence of habitat and microhabitat on carabid (Coleoptera: Carabidae) assemblages in four stand types. Can. Entomol. 2003, 135, 337-357. [CrossRef]

2. Latty, E.F.; Werner, S.M.; Mladenoff, D.J.; Raffa, K.F.; Sickley, T.A. Response of ground beetles (Carabidae) assemblages to logging history in northern hard wood-hem lock forests. For. Ecol. Manag. 2006, 222, 335-347. [CrossRef]

3. Fuller, R.J.; Oliver, T.H.; Leather, S.R. Forest management effects on carabid beetle communities in coniferous and broadleaved forests: Implications for conservation. Insect Conserv. Divers. 2008, 1, 242-252. [CrossRef]

4. Thiele, H.U. (Ed.) Carabid Beetles in Their Environments: A Study on Habitat Selection by Adaptations in Physiology and Behaviour; Springer: Berlin/Heidelberg, Germany; New York, NY, USA, 1977.

5. Slade, E.M.; Ritta, T. Interacting effects of leaf litter species and macrofauna on decomposition in different litter environments. Basic Appl. Ecol. 2012, 13, 423-443. [CrossRef]

6. Błońska, E.; Lasota, J.; Piaszczyk, P.; Wiecheć, M.; Klamerus-Iwan, A. The effect of landslide on soil organic carbon stock and biochemical properties of soil. J. Soils Sediments 2017, 18, 2727-2737. [CrossRef]

7. Błońska, E.; Kacprzyk, M.; Spólnik, A. Effect of deadwood of different tree species in various phases of decomposition on biochemical soil properties and carbon storage. Ecol. Res. 2017, 32, 193-203. [CrossRef]

8. Piaszczyk, W.; Błońska, E.; Lasota, J. Soil biochemical properties and stabilization soil organic matter in relation to deadwood of different species. FEMS Microbiol. Ecol. 2019, 95, fiz011. [CrossRef]

9. Watts, D.B.; Torbert, H.A.; Feng, Y.; Prior, S.A. Soil microbial community dynamics as influenced by composted dairy manure, soil properties, and landscape position. Soil Sci. 2010, 175, 474-486. [CrossRef]

10. Wolińska, A.; Stępniewska, Z. Dehydrogenase activity in the soil environment. In Dehydrogenases; InTech: Rijeka, Croatia, 2012; pp. 183-210.

11. Stevens, V. The Ecological Role of Coarse Woody Debris: An Overview of the Ecological Importance of CWD in BC Forests; Working Paper 30/1997; Ministry of Forests: Victoria, BC, Canada, 1997.

12. Jönsell, M. The effects of forest biomass harvesting on biodiversity. In Sustainable Use of Forest Biomass for Energy. A Synthesis with Focus on the Baltic and Nordic Region; Röser, D., Asikainen, A., Raulund-Rasmussen, K., Stupak, I., Eds.; Springer: Dordecht, The Netherlands, 2008; pp. 129-154.

13. Wright, P.; Cregger, A.M.; Souza, L.; Sanders, N.J.; Classen, A.T. The effect of insects, nutrients, and plant invasion on community structure and function above- and belowground. Ecol. Evol. 2014, 4, 732-742. [CrossRef]

14. Jones, A.G.; Scullion, J.; Ostle, N.; Oakley, S.; Di Dio, A.; Gwynn-Jones, D. Plant community composition and an insect outbreak influence phenol oxidase activity and soli-litter biochemistry in a sub-Arctic birch heath. Polar Biol. 2015, 38, 505-516. [CrossRef]

15. Szyszko, J.; Szwerk, A.; Malczyk, J. Animals as an indicator of carbon sequestration and valuable landscapes. ZooKeys 2011, 100, 565-573. [CrossRef] [PubMed]

16. Błońska, E.; Lasota, J.; Tullus, A.; Lutter, R.; Ostonen, I. Impact of deadwood decomposition on soil organic carbonsequestration in Estonian and Polish forests. Ann. For. Sci. 2019, 76, 102. [CrossRef]

17. Piaszczyk, W.; Lasota, J.; Błońska, E. Effect of Organic Matter Released from Deadwood at Different Decomposition Stages on Physical Properties of Forest Soil. Forests 2020, 11, 24. [CrossRef]

18. Lövei, G.L.; Sunderland, K.D. Ecology and behavior of ground beetles (Coleoptera: Carabidae). Annu. Rev. Entomol. 1996, 41, 231-256. [CrossRef]

19. Cvetkovska-Gjorgjievska, A.; Hristovski, S.; Prelić, D.; Jelaska, L. Šerić; Slavevska-Stamenković, V.; Ristovska, M. Body size and mean individual biomass variation of ground-beetles community (Coleoptera: Carabidae) as a response to increasing altitude and associated vegetation types in mountainous ecosystem. Biologia 2017, 72, 1059-1066. [CrossRef] 
20. Paletto, A.; Tosi, V. Deadwood density variation with decay class in seven tree species of the Italian Alps. Scand. J. For. Res. 2010, 25, 164-173. [CrossRef]

21. Herrmann, S.; Kahl, T.; Bauhus, J. Decomposition dynamics of coarse woody debris of three important central European tree species. For. Ecosyst. 2015, 2, 27. [CrossRef]

22. Fravolini, G.; Egli, M.; Derungs, C.; Cherubini, P.; Ascher-Jenull, J.; Gómez-Brandón, M.; Bardelli, T.; Tognetti, R.; Lombardi, F.; Marchetti, M. Soil attributes and microclimate are important drivers of initial deadwood decay in sub-alpine Norway spruce forests. Sci. Total Environ. 2016, 569, 1064-1076. [CrossRef]

23. Hararuk, O.; Kurz, W.A.; Didion, M. Dynamics of dead wood decay in Swiss forests. For. Ecosyst. 2020, 7, 1-16. [CrossRef]

24. Simpson, E.H. Measurement of diversity. Nature 1949, 163, 688. [CrossRef]

25. Shannon, C.E. A mathematical theory of communication. Bell Syst. Tech. J. 1948, 27, 379-423. [CrossRef]

26. Burakowski, B.; Mroczkowski, M.; Stefańska, J. Chrzaszzze-Coleoptera. Biegaczowate—Carabidae, Część I. Katalog Fauny Polski, cz. XXIII, t. 2, nr 20 [Catalogue of Beetles-Coleoptera. Ground Beetles-Carabidae, Part I. Catalogue of Fauna of Poland Part XXIII]; PWN: Warsaw, Poland, 1973; Volume 2.

27. Burakowski, B.; Mroczkowski, M.; Stefańska, J. Chrzaszcze-Coleoptera. Biegaczowate-Carabidae, Część II. Katalog Fauny Polski, cz. XXIII, t. 3, nr 22 [Catalogue of Beetles-Coleoptera. Ground Beetles-Carabidae, Part II. Catalogue of Fauna of Poland Part XXIII]; PWN: Warsaw, Poland, 1974; Volume 3.

28. Hůrka, K. Carabidae of the Czech and Slovak Republices; Kabourek: Zlin, Czech Republic, 1996.

29. de Jong, Y.; Verbeek, M.; Michelsen, V.; Bjørn, P.D.P.; Los, W.; Steeman, F.; Bailly, N.; Basire, C.; Chylarecki, P.; Stloukal, E.; et al. Fauna Europaea-All European animal species on the web. Biodivers. Data J. 2014, 2, e4034. [CrossRef] [PubMed]

30. Paje, F.; Mossakowski, D. pH-preferences and habitat selection in carabid beetles. Oecologia 1984, 64, 41-46. [CrossRef]

31. Magura, T.; Tóthmérész, B.; Zoltán, E. Diversity and composition of carabids during a forestry cycle. Biodivers. Conserv. 2003, 12, 73-85. [CrossRef]

32. Głowaciński, Z.; Makomaska-Juchiewicz, M.; Połczyńska-Konior, G.; Pawłowski, J. (Eds.) Czerwona Lista Zwierząt Ginacych $i$ Zagrożonych w Polsce (Red List of Threatened and Endandered Animals in Poland); Instytut Ochrony Przyrody PAN: Krakow, Poland, 2002.

33. Bobiec, A.; Gutowski, J.M.; Laudenslayer, W.F.; Pawlaczyk, P.; Zub, K. (Eds.) The Afterlife of a Tree; WWF Poland: Warsaw, Poland, $2005 ;$ p. 253.

34. Kehler, D.; Bondrup-Nielsen, S.; Corkum, C. Beetle diversity associated with forest structure including deadwood in softwood and hardwood stands in Nova Scotia. Proc. Nova Scotian Inst. Sci. 2004, 42, 227-239. [CrossRef]

35. Sota, T. Altitudinal variation in life cycles of carabid beetles: Life-cycle strategy and colonization in alpine zones. Arct. Alp. Res. 1996, 28, 441-447. [CrossRef]

36. Fraser, L.H.; Bassett, E. Effects of Cattle on the Abundance and Composition of Carabid Beetles in Temperate Grasslands. J. Agric. Stud. 2015, 3, 36-47. [CrossRef]

37. Gobbi, M.; Rossaro, B.; Vater, A.; de Bernardi, F.; Pelfini, M.; Brandmayr, P. Environmental features influencing Carabid beetle (Coleoptera) assemblages along a recently deglaciated area in the Alpine region. Ecol. Entomol. 2007, 32, 682-689. [CrossRef]

38. Magura, T.; Ferrante, M.; Lövei, G.L. Only habitat specialists become smaller with advancing urbanization. Glob. Ecol. Biogeogr. 2020, 29, 1978-1987. [CrossRef]

39. Hodkinson, I.D. Terrestrial insects along elevation gradients: Species and community responses to altitude. Biol. Rev. 2005, 80, 489-513. [CrossRef]

40. Jung, J.-K.; Kim, S.T.; Lee, S.; Park, C.-G.; Park, J.K.; Lee, J.-H. Community structure of ground beetles (Coleoptera: Carabidae) along an altitudinal gradient on Mt. Sobaeksan, Korea. J. Asia Pac. Entomol. 2012, 15, 487-494. [CrossRef]

41. Magura, T.; Tóthmérész, B.; Elek, Z. Impacts of leaf-litter addition on carabids in a conifer plantation. Biodivers. Conserv. 2005, 14, 475-491. [CrossRef]

42. Sroka, K.; Finch, O.-D. Ground beetle diversity in ancient woodland remnants in north-western Germany (Coleoptera, Carabidae). J. Insect Conserv. 2006, 10, 335-350. [CrossRef]

43. Schiegg, K. Effects of dead wood volume and connectivity on saproxylic insect species diversity. Écoscience 2000, 7, 290-298. [CrossRef]

44. Stenbacka, F.; Hjältén, J.; Hilszczański, J.; Dynesius, M. Saproxylic and non-saproxylic beetle assemblages in boreal spruce forests of different age and forestry intensity. Ecol. Appl. 2010, 20, 2310-2321. [CrossRef] [PubMed]

45. Lassauce, A.; Paillet, Y.; Jactel, H.; Bouget, C. Deadwood as a surrogate for forest biodiversity: Meta-analysis of correlations between deadwood volume and species richness of saproxylic organisms. Ecol. Indic. 2011, 11, 1027-1039. [CrossRef]

46. Nittérus, K.; Gunnarsson, Á.; Gunnarsson, B. Manipulated structural variability affects the habitat choice of two ground-living beetle species in a laboratory experiment. Èntomol. Fenn. 2008, 19, 122-128. [CrossRef]

47. Skłodowski, J. Survival of carabids after windthrow of pine forest depends on the presence of broken tree crowns. Scand. J. For. Res. 2020, 35, 1-10. [CrossRef]

48. Sippola, A.L.; Siitonen, J.; Jokimäki, J.; Inkeröinen, J.; Kallio, R. Effects of forest structure and vegetation on diversity of beetles (Coleoptera) and birds in north-boreal pine forests. In Ecosystem Monitoring and Protected Areas; Science and Management of Protected Areas Association: Wolfville, NS, Canada, 1992; pp. 197-203. 
49. Økland, B.; Bakke, A.; Hågvar, S.; Kvamme, T.F. What factors influence the diversity of saproxylic beetles? A multiscaled study from a spruce forest in southern Norway. Biol. Conserv. 1996, 5, 75-100. [CrossRef]

50. Gongalsky, K.B.; Cividanes, F.J. Distribution of carabid beetles in agroecosystems across spatial scales-A review. Balt. J. Coleopterol. 2008, 1, 15-30.

51. Niemelä, J.; Halme, E. Habitat associations of carabid beetles in fields and forests on the Aland Islands, SW Finland. Ecography 1992, 15, 3-11. [CrossRef]

52. Shevlin, K.D.; Hennessy, R.; Dillon, A.B.; O'Dea, P.; Griffin, C.T.; Williams, C.D. Stump-harvesting for bioenergy probably has transient impacts on abundance, richness and community structure of beetle assemblages. Agric. For. Entomol. 2017, 19, 388-399. [CrossRef]

53. Vician, V.; Svitok, M.; Kočík, K.; Stašiov, S. The influence of agricultural man-agement of ground beetle (Coleoptera: Carabidae) assemblages. Biologia 2015, 70, 240-251. [CrossRef]

54. Vician, V.; Svitok, M.; Michalková, E.; Lukáčik, I.; Stašiov, S. Influence of tree species and soil properties on ground beetle (Coleoptera: Carabidae) communities. Acta Oecologica 2018, 91, 120-126. [CrossRef]

55. Kuperman, R.G. Relationships between soil properties and community structure of soil macroinvertebrates in oak-hickory forests along an acidic deposition gradient. Appl. Soil Ecol. 1996, 4, 125-137. [CrossRef]

56. Nietupski, M.; Sowiński, P.; Sądej, W.; Kosewska, A. Content of organic C and pH of bog and post-bog soils versus the presence of ground beetles Carabidae in Stary Dwór near Olsztyn. J. Elem. 2010, 15, 581-591. [CrossRef]

57. Sądej, W.; Kosewska, A.; Sądej, W.; Nietupski, M. Effects of fertilizer and land-use type on soil properties and ground beetles ommunities. Bull. Insectol. 2012, 65, 239-246.

58. Jukes, M.R.; Peace, A.J.; Ferris, R. Carabid beetle communities associated with coniferous plantations in Britain: The influence of site, ground vegetation and stand structure. For. Ecol. Manag. 2001, 148, 271-286. [CrossRef]

59. Lasota, J.; Błońska, E.; Piaszczyk, W.; Wiecheć, M. How the deadwood of different tree species in various stages of decomposition affected nutrient dynamics? J. Soils Sediments 2017, 18, 2759-2769. [CrossRef] 